\title{
The Importance of Business Anthropology: Its Unique Contributions
}

\author{
Ann T. Jordan \\ University of North Texas
}

When I entered the field of business anthropology in the 1980s, it was an exciting and new development in anthropology, although anthropologists had been in business since the 1930s. What we experienced in the 1980s was actually a revival of a field that had been for the most part inactive for decades. Since the 1980s, the importance of business anthropology has exploded both inside the discipline and outside of it in the world of public life. The reasons for this explosion are complex but at the heart of them is the importance of what anthropologists bring to business. We bring a special way of looking and of thinking and consequently we come to conclusions not reached by others.

\section{WHY WE NEED BUSINESS ANTHROPOLOGY}

Our special way of looking and thinking is a result of the circumstances of our research over the last century. Anthropologists originally specialized in studying people and cultures very different from their own. For example, Bronislaw Malinowski (1984), spent years studying the Trobriand Islanders in the Pacific in the 1910s, and Donald Cole (1975) lived for extensive periods with the Al Murrah Bedouin in Saudi Arabia in the 1960s. In such cases, the anthropologist was entering a foreign world where he or she not only did not speak the language, know the food, or know how to survive on his own, but did not know the rules of acceptable behavior. The only way to learn was to watch and, when possible, to participate; this is what anthropologists call participant observation and it continues to be a staple technique in our toolkit of methods. As Roger and Felix Keesing have explained:

Whether the setting is city, town, village or jungle hut, the mode of anthropological research is in many important respects the same. Most essential, it entails a deep emersion into the life of a people.... [The anthropologist] learns their language and tries to learn their mode of life....His place and his task are in many ways like those of an infant. He does not understand the noises, the visual images, the smells that carry rich meanings for those around him....He can administer questionnaires to find out about the world he has entered little better than an infant can, and for many of the same reasons: he does not know what the questions are that have answers. (Keesing and Keesing, 1971, p.12-13) 
This quandary for the anthropologist is at the heart of all our research and also explains much of our value in the modern business world. Our research techniques differ from those of most other social scientists in that ours are primarily qualitative (ethnographic) while the techniques of the others are primarily quantitative. Ours are qualitative because those were the only types of techniques we could use in the unusual and foreign settings where we could not have administered a questionnaire because we did not know what questions to ask nor did we know how to ask questions in a way that would be understood. Consequently, we used participant observation and open-ended interviews in which the questions were so broad that the respondent could talk about just about anything. This was more than just an understanding of people's feelings; this was a way to learn and to slowly build up an understanding of the way of life of a people.

Today, these and our other related techniques have become highly prized in the business world. As an organizational anthropologist, when I enter an organization, I enter as an infant; I put away all my understanding of organizations and business, as best I can, and try to see the organization as Malinowski saw the Trobrianders when first stepping into their very human but very different world. In other words, I try to see it with fresh eyes and make no assumptions about understanding things. Then I ask questions that are open-ended because I have no idea what is important. For example, in a study of leadership in self-managed work teams, my colleagues and I interviewed all members of 25 teams across six organizations about their experiences with self-managed work teams. Rather than focusing specifically on leadership, we asked them about six broad topics: 1) career history, 2) company history, 3) teaming process,4) content of team's work, 5) personal definition of successful leader and team, and 6) perceptions of advantages and disadvantages of teams.

The open ended nature of these questions allowed them to tell us about their experiences in work teams and led us to the conclusion that leadership was too narrow a focus for our study of success in self-managed teams. Had we begun by just interviewing employees about leadership, we would have never learned the many other reasons for work team success (Jordan 1999). It is this open-ended approach that allows information to bubble up from direct interaction with the subjects of the study and provides us, the researchers, with information we would never have thought to ask about. This is what broadens our understanding of a problem beyond what we could have assumed the issues to be at the beginning of the study. It is this ability to analyze the raw data we gather from interviews, observation and our other techniques and to find answers that makes anthropological work valuable in business. Often the answers we find are broader than the questions that were originally asked.

Anthropologists tackle different types of problems in the business world. Here are examples of some of these:

Work Processes. Here we study how to improve work processes by observing how people work. For all of us, there are probably ways our processes could be improved that would make our work easier and more efficient. Anthropologists are specialists in looking. For example, Lucy Suchman observed the use of Xerox machines and discovered that multiple features on a machine were not always making work easier. Machines had gotten so complicated that the untrained user could not just walk up to a machine and easily figure out how to make a single copy. As a result of Suchman's research, Xerox now makes all copy machines, no matter how complex, with a single, green, copy button so that anyone can easily perform the simple task of making a copy. Another example is Bonnie Nardi's work at Hewlett-Packard where she helped 
develop a more efficient spreadsheet after seeing that the one developed by the method engineers was not being used in the way they had imagined (Weise, 1999).

Group Behavior. Anthropological work is always focused on the behavior of the group. Boas and Malinowski were looking for culture, which I define as an integrated system of learned, shared ideas (thoughts, ideals, and attitudes), behaviors (actions), and material artifacts (objects) characteristic of a group. Anthropologists are also interested in individual behavior but primarily as individual behavior agrees with, differs from, or impacts group behavior. Consequently in working in business, we are similarly focused. This might mean understanding the culture of an organization. In the work team study I mentioned above, this meant understanding how an entire organization dealt with work teams and learning that the organization needed to invest in manager support, appropriate reward systems and up-front training for self-managed teams to be a success (Jordan, 1999). In marketing, this might mean following around and interviewing college students using laptops to see how, when, and where they use them. This improved understanding of the behavior of this group could better inform a computer manufacturing company about potential design changes which would further attract students to their machines.

Organizational Change. Many issues of organizational change can benefit from anthropological study. For example, in another study I conducted, I studied a merger that was not going well. The two cultures of the merged companies were at odds and the new management was frustrated that it could not get one of the formerly independent companies to change and conform to its requests. In observing and talking to employees of both formerly independent companies, it became clear that the members of the uncooperative group felt that change would cost them market share and that the new management did not understand issues involved in their particular market. The reasons for the resistance to change were different from the ones management was assuming (Jordan, 2003).

Consumer Behavior. John Sherry (1995) has suggested that consumer behavior is an adaptive strategy shaping an individual's quality of life and that marketing therefore is a directed intervention strategy of planned change. Consequently for anthropologists, the study of marketing and consumption is the study of adaptive strategies and of directed, planned change. These are areas that are familiar territory in the study of cultures. Marketing is interested in group behavior and as several of the studies already mentioned, like the one of student use of computers, demonstrate; anthropologists can contribute to the understanding of group behavior and provide suggestions on marketing strategies. Susan Squires (2002) conducted a study for a manufacturer of personal care products who wanted to know if people would use hand lotion and tissues at the office as well as at home. Her research with office workers revealed that they would if these products were packaged in office appropriate containers, rather than ones designed for the home and bathroom.

Product Design: An area in business anthropology that has grown exponentially in the last decade is product design. Most product design firms employ ethnographic (qualitative and anthropological) techniques in the new realization that these techniques are a valuable way to get a rich understanding of what consumers want and can provide the designers with ideas for new products. In a study of office furniture for Steelcase, anthropological techniques were used to discover that people were not only working in their offices and conference rooms but in every place where employees collected, like the hallways and coffee rooms. These were places Steelcase previously considered 'dead space,' but now reconsidered as opportunities to develop 
new products like whiteboards, markers and chairs that could be placed in these spaces to facilitate the work already going on there (Wasson, 2000).

Globalization and Diversity. It is obvious today that business has gone global. Anthropologists have always been culture brokers who helped cultural groupings understand each other. This continues to be at the heart of our work in this globalized and diverse workforce of today. Many anthropologists are involved in assisting multinational corporations understand the cultures of the many countries in which they operate. As one Japanese industrialist remarked, the approaches and operations of U.S. and Japanese companies are 95 percent alike but it is the 5 percent difference that really matters (Harris and Moran, 1987). Tomoko Hamada (1991) has spent decades helping Japanese and U.S. businesses understand each other. In a study of a joint venture between companies in the two countries, she showed how everything from corporate structure to factory layout to product appearance had to be negotiated between the two different (U.S. and Japanese) cultural groups. In my own research in a tertiary care hospital in Riyadh, Saudi Arabia, I was studying an organization which employed individuals with 64 different passports. How do individuals from so diverse backgrounds interact in a working environment in health care? I learned that two of these diverse cultures were the most significant in creating the hospital culture. They were the U.S., who had set up the hospital initially, and Saudi Arabia, where the hospital was located. Thirty years after the hospital's inception, the tensions between these two, very different, cultural ways were still being negotiated daily (Jordan 2008).

Today business anthropology is effectively divided into three fields: 1) organizational anthropology (the study of complex organizations to include their cultures, work processes, and change directives), 2) anthropology of marketing and consumer behavior, and 3) design anthropology (product and services design). All of these rely on basic anthropological methodology and theory and involve studying the kinds of problems described above. A thread running through all three of these fields is issues of diversity and globalization.

So why do we need business anthropology? Most social scientists specialize in statistical approaches to understanding behavior. Anthropologists value these quantitative approaches and use them as well. Quantitative data provides a valuable summary and analysis of the subject and then qualitative data adds the rich details that give the quantitative data depth and meaning in the real world. Anthropologists specialize in qualitative (ethnographic) data collection and analysis. We have a specific approach to understanding human behavior which goes far beyond just studying feelings. We are interested in group behavior and in culture. We look at the ways the customs and beliefs of a people are integrated (holism); we compare groups of people around the world and across cultures to get a larger understanding of human behavior and to serve as brokers between cultural groups (cross-cultural comparison); and we try to understand behavior from the participants point of view rather than our own (cultural relativity). All of these make us valuable to the field of business.

\section{THE RAPID GROWTH OF BUSINESS ANTHROPOLOGY}

As I mentioned earlier, anthropologists have been in business since the 1930s. The field began in Chicago when Lloyd Warner, an American anthropologist who had studied the Murngin Aborigines of Australia, participated as one of the scientists conducting research at Western Electric's Hawthorne Works manufacturing plant in 1931. Warner was using anthropological, qualitative research techniques and theory to study employee interactions at work. This research was significant in 1) the realization by scientists that understanding human relations was crucial 
to understanding performance in organizations and 2) in the creation of human relations as a field of study. This was also the beginning of industrial anthropology, the earliest name for the field of business anthropology.

A decade later, Conrad Arensberg and Eliot Chapple and other industrial anthropologists at Harvard started the Society for Applied Anthropology (SfAA), the oldest and largest applied anthropology, professional association in North America today. These individuals trained others and the field of industrial anthropology spread through American universities. They published many studies of work like one of technology change on an assembly line at IBM's Endicott plant (Richardson and Walker 1948) and another of a strike at Chicago's Inland Steel Container Company (Whyte, 1951). In 1946, Burleigh Gardner and Lloyd Warner and other business partners formed Social Research, Incorporated, the first management consulting firm to include business anthropologists and to use anthropological techniques and theory.

Another important business anthropologist came to prominence in the 1950s. Edward T. Hall worked for the U.S. Department of State in the 1950s providing training in cross-cultural communication to technicians who would be working outside North America. He wrote several books, like The Silent Language, which have been seminal in the field of intercultural communications and intercultural training. They deal with cross-cultural communication, both verbal and nonverbal, and differing cultural perceptions of basic concepts like time and space. His work continues to be popular around the world.

In the 1960s and 1970s there was a change of perspective in U.S. anthropology about the importance of working in business. The issue was ethics. This was a time of political turmoil in the U.S. and the U.S. government was thought to be recruiting anthropologists for covert operations in first Latin America and then Vietnam. Most anthropologists opposed what they saw as spying on innocent people and in 1971, the American Anthropological Association (AAA), the main professional association of all U.S. anthropologists, amended its Principles of Professional Responsibility to include a clause prohibiting research when the outcome of the research would not be available to the general public. This effectively shut down all consulting work for corporations since corporations typically want proprietary control of such work. Business anthropology disappeared from view during the decades of the 1960s and the 1970s.

It was reborn in the $1980 \mathrm{~s}$ and has been expanding ever since. In the $1980 \mathrm{~s}$, management scientists discovered culture. This was partly due to the rise of Japan as an economic rival for the U.S. As Toyotas began to replace Chevrolets on the streets of American towns, the U.S. became envious of and worried by Japan's success. Four popular management books spurred the interest in culture and management. These were: Theory $Z$ by William Ouchi (1981), The Art of Japanese Management by Richard Pascale and Anthony Athos (1981), Corporate Culture by Terrence Deal and Allan Kennedy (1982), and In Search of Excellence by Thomas Peters and Robert Waterman (1982). Other management scientists were conducting quantitative research on management cross-culturally (Hofstede 1980). These works by management scientists inspired anthropologists to jump back into the field of organizational studies. For many of us, these books were useful but had multiple flaws that, as anthropologists, we saw as significant. They lacked anthropological rigor in understanding other cultures and the quantitative techniques they used led to over generalization and stereotyping. It was time for anthropologists to reenter the field.

There was new interest from management in anthropological techniques and several anthropologists published articles in management journals on the subject of anthropological methodology (Morey and Luthans, 1984). Work began appearing in anthropological journals as well. The Society for the Anthropology of Work in its Anthropology of Work Review published 
a special issue on organizational culture (Sachs, 1989). The American Anthropologist, published by the AAA and the primary journal of anthropology in the U.S., and Human Organization, the journal published by SfAA, began to include these articles as well. Examples of these are Elizabeth Briody and Marietta Baba's (1991) article on repatriation of workers sent on overseas assignments by a U.S. corporation and Allen Batteau's (2000) overview of issues in organizational cultures, both published in the American Anthropologist. Anthropologists were also publishing books on specific topics in business like Dubinskas' (1988) edited book on ethnographies of high-technology industries and Hamada (1991) on issues for Japanese and U.S. joint ventures. Other publications included edited books on organizational culture and crosscultural management (Serrie, 1986; Hamada and Jordan, 1990; Sibley and Hamada, 1994; Jordan, 1994).

Meanwhile, anthropology's influence in business schools was growing. Especially noteworthy was the hiring of anthropologists in marketing with John Sherry at Northwestern University, Grant McCracken at Harvard University and Eric Arnould at University of Nebraska. Sherry (1995) published an edited volume of anthropological work in marketing and consumer behavior. In the 1990s, the field of design anthropology began to take shape. Anthropologists at Xerox, like Lucy Suchman, were influential in the inception of this movement (Wasson, 2000).

In the last decade, the two fields of anthropology of marketing and consumer behavior and of design anthropology have further crystallized and grown. In the first, anthropologists John Sherry and Eric Arnould were instrumental in developing the Consumer Culture Theory (CCT) Conference, first held at University of Notre Dame in 2006. At this annual conference the papers and posters reflect the CCT approach which "basically considers consumption and its involved behavioral choices and practices as social and cultural phenomena - as opposed to psychological or purely economic phenomena. CCT, in the words of one of the summarizing articles about the field, 'refers to a family of theoretical perspectives that address the dynamic relationship between consumer actions, the marketplace, and cultural meanings' (www.consumerculturetheory.org)." Most of the scientists attending and presenting at this conference teach in business schools and are committed to understanding the cultural meanings of consumer behavior. The conference draws presenters from around the world, as evidence by the international presence at the most recent conference in June, 2010, at the University of Wisconsin, Madison. The conference and the organization have shaped this new field of consumer culture theory in marketing.

In design anthropology, a similarly significant conference is the Ethnographic Praxis in Industry Conference (EPIC) which begun in 2005 held its sixth conference in Tokyo in 2010. This conference was again started by a group of anthropologists to include Ken Anderson at Intel, Tracey Lovejoy at Microsoft, Jeanette Blomberg at IBM, and Christina Wasson at University of North Texas. According to its website;

The Ethnographic Praxis in Industry Conference (EPIC) aims to bring together people who are actively thinking about the theoretical and methodological development of ethnography in industry practice. We want to draw people who are both working in industry, as well as those who consult or collaborate with industry. We are aiming to create a collaborative venue where those practicing their ethnographic training in the corporate setting can benefit from mutual support and sharing information. (http://epiconference.com) 
This conference is attended by design anthropologists, designers and others in industry and in design firms who use ethnographic techniques to develop new product ideas. Design firms are hungry for anthropologists and their approaches. At the 2009 conference in Chicago, multiple local design firms participated in showcasing anthropological (ethnographic) techniques. Publications in this field are growing with the annual EPIC proceedings and other works like Sunderland and Denny's (2007) book which provides a rigorous overview of theory and practice in the use of ethnography. The field is an exciting example of the multidisciplinary collaboration of anthropologists, designers and others interested in this approach to product design.

Business anthropology in the U.S. is a growth industry. More and more applied programs are teaching courses in this new field. The universities with such courses include the University of North Texas, Wayne State University in Michigan, and San Jose State University in California. Many students from the graduate programs are out in the workplace and using business anthropology to help others.

\section{THE ETHICS OF BUSINESS ANTHROPOLOGY}

In the U.S., the growth of business anthropology has been accompanied by a serious discussion of the ethical issues it involves. The primary ethical guideline in anthropology has been to do no harm to the subjects of one's study. The subjects of one of my organizational studies, for example, are the workers I interview. What if their corporate bosses use the study against these workers I interviewed? In a marketing study, what if the information is used to try to manipulate people into buying products? In a design study, what if the information is used to create new products people didn't really need but will now waste their money buying? In U.S. anthropology there has been great concern about these ethical issues because the employee and the everyday consumer are the subjects of our research and they could be harmed by the information we gather. Consequently, anthropologists are required to think through these issues before beginning a study. If it appears that the individuals they will be studying can be harmed by the work, they do not undertake the study. For example, if it appears the corporate bosses are only interested in increasing profit for the shareholders at the expense of the employees or the community, then I do not undertake the work. This is also the reason anthropologists do not work in competitive intelligence. No work should be illegal and no work should be done under false pretenses. I should always be able to tell those I am studying that I am an anthropologist conducting a study and I should always be able to tell them why I am conducting the study and what it is about. It is unethical for me to misrepresent my interests. By following these guidelines as outlined by the American Anthropological Association, we are able to ethically conduct business anthropological work.

\section{MY EXPERIENCE AS A BUSINESS ANTHROPOLOGIST}

I became interested in business anthropology in the early 1980s when Deal and Kennedy's Corporate Culture became a best-selling book. After reading it and seeing the excitement it generated from corporate CEOs, and managers at all levels, I realized that this was a field for anthropologists to explore. While the ideas in the book were innovative, the treatment of culture was superficial and I felt that an anthropologist was much better trained to write about the topic of corporate culture. Consequently, I began research on the topic that has since become known as organizational culture because all complex organizations have culture, not just corporations. To 
my anthropologically-trained mind, there was no such thing as a "strong" or "weak" culture. Every organization had a unique culture. I was intrigued by the applying of the anthropological construct "culture" to organizations. Could it really be used in this way? I thought so, but felt it needed to be thought through. For example, in anthropology, the construct was used traditionally to apply to an individual's primary culture; in other words, it applied to the culture one was socialized into from birth.

Organizational cultures were obviously much less substantial in one's life. They were entered into later in life and could be transitory since one could change jobs repeatedly. I wondered if they were really culture at all. I began conducting research and in 1988, I began presenting my ideas at meetings. My first organizational study was of a merger and the difference between the "cultures" of the two merged companies convinced me that the construct was useful in understanding organizations. In the late 1980s and early 1990s, the anthropological community was not particularly receptive to what was considered a "watered down" use of the construct culture. Organizational culture was vastly different from culture of an entire society, like the Trobriand Islanders. I was told repeatedly that my use of the term was a misuse. At the same time, the concept was getting attention in management studies and several individuals championed it (Schein, 2004; Martin, 1992). There was also talk that the topic of corporate culture was just a fad without real substance and would quickly die.

It was not a fad. The concept of corporate culture and organizational culture took hold in the popular mind in the U.S. and at this point, every management person I talk with knows what it is. It is used in advertizing commercials on radio and appears frequently in the popular press to refer to all kinds of group-held beliefs. Organizational culture is understood to be part of the fabric of an organization and continues to be studied in both management and anthropology because it describes something intangible about organizations. This is something in the messy, human, underpinnings of an organization that there was no way to describe before. It has given that phenomena a name. At the same time in anthropology, the construct "culture" was coming under attack. We began to realize that these nice, neat systems we had identified as "culture" never exited as closed systems. The Trobrianders might live on remote islands in the South Pacific but they had long had contact with other people and been influenced by them. This was more than just an example of diffusion, it was a breaking apart of the idea of culture. After all, in the highly diverse and rapidly changing U.S., who could describe the U.S. culture, except to say that it was highly diverse and rapidly changing? In this new environment, my use of culture in organizations began to make more sense. An individual's life meant he or she participated in multiple cultural groupings: work, ethnicity, nationality, gender, life stage - just to name a few. This made more sense to me as I studied a phenomenon in organizations that seemed like culture.

It turned out, that I had gotten in on the beginning of the development (or the re-development if you consider the history of business anthropology going back to the 1930s) of an exciting new field. I thought that if our anthropological methods and theories were worth anything, then we ought to be able to use them to understand organizations. I was thrilled to be practicing my craft in this new laboratory: the organization. It was a place where one could watch culture form and change relatively quickly. I thought this research could inform the other areas of anthropology. Indeed today, the use of culture to describe norms of organizational life has become routine in anthropology and is no longer challenged. The construct culture needed to be broken apart in order to be rebuilt in a new and more useful way. At the same time that organizational anthropology was developing, so was anthropology of marketing and consumer behavior. Design 
anthropology would develop shortly after. Still there was no book that brought the fields together and this I tried to do in my 2003 book, Business Anthropology.

\section{THE FUTURE OF BUSINESS ANTHROPOLOGY}

My career in business anthropology has been a good one. It has led me to conduct research in multiple countries and with multiple organizations. It has led me into the field of consulting. I continue my research, consulting, and training of graduate students in this field. The future for business anthropology in the U.S. is bright as more and more anthropologists work outside academia in organizations, consulting firms, design studios and marketing agencies. I am also happy to see the development of the field outside the U.S. There are many researchers around the world, in China, Japan, Australia, Central America, and Europe, working on issues in organizations, design, and consumer behavior. I am pleased, for example, to be active in the International Union of Anthropological and Ethnological Sciences and in its Enterprise Anthropology division. Business anthropology is a global field and collaborations with researchers around the world can only strengthen our area of research and practice. I am pleased to see this international interest in business anthropology and am looking forward to joining my colleagues all over the world in research, student training, and consulting in the future.

\section{REFERENCES}

Batteau, Allen W. (2000). Negations and Ambiguities in the Cultures of Organization. American Anthropologist 102(4), 726-740.

Briody, Elizabeth K., and Marietta L. Baba (1991). Explaining Differences in Repatriation Experiences: The Discovery of Coupled and Decoupled Systems. American Anthropologist 93(2): 322-43.

Cole, Donald Powell (1975). Nomads of the Nomads: The Al Murrah Bedouin of the Empty Quarter. Arlington Heights, IL: AHM Publishing Corporation.

Consumer Culture Theory Website (2010). www.consumerculturetheory.org. Accessed June 30, 2010 .

Deal, Terrence E. and Allan A. Kennedy (1982). Corporate Cultures. Reading, MA: AddisonWesley.

Dubinskas, Frank A., ed. (1988). Making Time: Ethnographies of High-Technology

Organizations. Philadelphia: Temple University Press.

Ethnographic Praxis in Industry Conference Website (2010). http://epiconference.com. Accessed June 30, 2010.

Hamada, Tomoko (1991). American Enterprise in Japan. Albany: State University of New York Press. 
Hamada, Tomoko, and Ann T. Jordan, eds. (1990). Cross-Cultural Management and Organizational Culture. Studies in Third World Societies, 42. Williamsburg: College of William and Mary, Department of Anthropology.

Harris, Philip R. and Robert T. Moran (1987). Managing Cultural Difference. Houston: Gulf Publishing.

Hofstede, Geert (1980). Culture's Consequences: International Differences in Work-Related Values. Beverly Hills: Sage.

Jordan, Ann T., ed. (1994). Practicing Anthropology in Corporate America: Consulting on Organizational Culture. (National Association for the Practice of Anthropology, Bulletin No.14).Washington DC: American Anthropological Association.

Jordan, Ann T. (1999). An Anthropological Approach to the Study of Organizational Change: The Move to Self-Managed Work Teams. Practicing Anthropology 21(4): 14-19.

(2003). Business Anthropology. Prospect Heights, Il: Waveland Press.

(2008). The Making of a Modern Kingdom: Transnational Partnerships in Saudi Arabia. In Elizabeth K. Briody and Robert Trotter II (eds.) Partnering for Organizational Performance. pp. 177-92. New York: Rowman and Littlefield Publishers.

Keesing, Roger M. and Felix M. Keesing (1971). New Perspectives in Cultural Anthropology. New York: Holt, Rinehart and Winston.

Martin, Joanne (1992). Cultures in Organizations: Three Perspectives. New York: Oxford University Press.

Malinowski, Bronislaw (1984[1922]). Argonauts of the Western Pacific. Prospect Heights, Il: Waveland Press.

Morey, Nancy C., and Fred Luthans (1984). An Emic Perspective and Ethnoscience Methods for Organizational Research. Academy of Management Review 9: 27-36.

Ouchi, William (1981). Theory Z. Reading, MA: Addison-Wesley.

Pascale, Richard Tanner, and Anthony G. Athos (1981). The Art of Japanese Management. New York: Simon and Schuster.

Peters, Thomas J., and Robert H. Waterman (1982). In Search of Excellence. New York: Warner Books.

Richardson, Frederik L. W. and Charles R. Walker (1948). Human Relations in an Expanding Company: A Study of the Manufacturing Departments in the Endicott Plant of the International Business Machines Corporation. New Haven: Yale University, Labor Management Center. 
Sachs, Patricia, ed. (1989). Anthropological Approaches to Organizational Culture. Theme Issue. Anthropology of Work Review 10(3).

Serrie, Hendrick, ed. (1986). Anthropology and International Business. Studies in Third World Societies, 28. Williamsburg: College of William and Mary, Department of Anthropology.

Schein, Edgar (2004). Organizational Culture and Leadership. San Francisco: John Wiley and Sons, Inc.

Sherry, John F., ed. (1995). Contemporary Marketing and Consumer Behavior: An Anthropological Sourcebook. Thousand Oaks, CA: Sage.

Squires, Susan (2002). Doing the Work: Customer Research in the Product Development and Design Industry. In Creating Breakthrough Ideas: The Collaboration of Anthropologists and Designers in the Product Development Industry. S. Squires and B. Byrne (eds.), pp. 103-124. Westport, CT: Bergin and Garvey.

Sunderland, Patricia L. and Rita M. Denny (2007). Doing Anthropology in Consumer Research. Left Coast Press.

Wasson, Christina (2000). Ethnography in the Field of Design. Human Organization 59(4): 377388.

Weise, Elizabeth (1999). Companies Learn Value of Grass Root Anthropologists Help Adapt Products to World Cultures. In USA Today. 26 May, p. 4d.

Whyte, William Foote (1951). Pattern for Industrial Peace. New York: Harper and Row. 